\title{
THE MEMORY WARD
}

\author{
Forgive and forget?
}

\section{BY WENDY NIKEL}

$\mathrm{L}$ iza was losing her memories. She hacked at her morning omelette and wondered what she'd lost overnight which familiar faces had turned into strangers, which moments were gone, lost like bubbles popped in mid-air, leaving no trace of their former existence.

"Coffee?" the nurse asked. Liza couldn't recall her name. Had she known it yesterday?

"Old Liza never drinks the stuff." Another woman with the same straight, white hair and same squarishness to her jaw shuffled into the next seat. Now here's someone Liza could never forget, leastways not while she still remembered anything at all. Every step of the way, from the cradle Gramps carved, to their wild days on the wrong side of the law, to the Memory Ward in this second-rate nursing home, Cousin Jessa had been there. "She'll have more orange juice though, if you've got some."

"Morning." Liza sighed as the nurse poured her more orange juice, orange juice she didn't even really want.

"You've got that look on your face." Jessa frowned. "You took out more memories last night?"

"Yeah, I did." Liza shrugged sheepishly. "I know it's been years, but ... I don't want to forget him."

Liza had been losing bits and pieces of her life for more than a decade now to that wretched disease. At least this way, when she extracted them into Memory Cubes, she could revisit them whenever she wanted to, even if they were gone from her mind.

Jessa scoffed. "Only a fool like you would try to save a memory by wiping it from your mind."

"Don't tell me you've never put anything into the Cubes."

"Course I have. Don't ask what." She shook a heap of sugar into her coffee. "That's the difference between us. You put stuff in there to remember it; I put stuff in there to forget it."

Liza must have already tucked away the memory of the first time she met him, because she couldn't recall a thing about it. She remembered later that year, though, when she told Jessa that she'd promised to go

straight, find an honest job, and take him up on his proposal. Jessa hadn't taken it too well.

"We're peas in a pod," Jessa said. "Partners in crime. And he's nothing - nothing - like us. You marry him and next thing you know, he'll be wanting kids and a house with a white picket fence and roast beef on the table every night. Is that really the kind of life you want?"

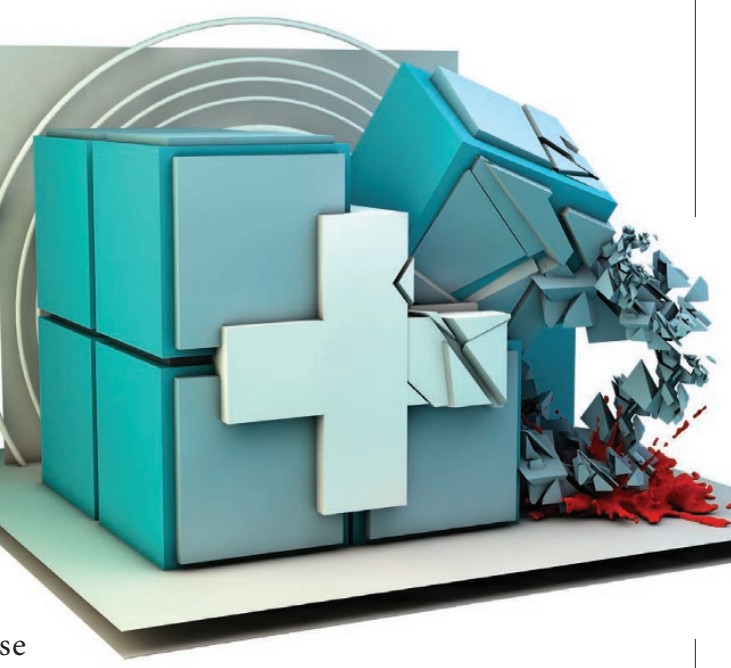

That was the one time in her life she stood up to Jessa; she couldn't help whom she loved.

Just thinking about him made Liza want to see him one last time, the way he was that night before their wedding, before everything went wrong ... before a sharp turn on a slick road stole away the love of her life.

Liza searched for a nurse on her way to the Cube cabinet. Somehow, although they usually hassled her all day, now that she needed one, they were nowhere to be found. She reached for the call button in her cardigan pocket, but the only thing there was the butter knife from the breakfast table. She really was losing her mind.

Never mind that, she thought, looking from the knife to the cabinet. They hadn't called her Lock-Pick Liza for nothing.

Moments later, the cabinet swung open. She scanned the Cubes, shooting a guilty glance over her shoulder. She couldn't remember the numerical code used to identify her cubes, but fortunately, they were also

$\rightarrow$ NATURE.COM Follow Futures: y @NatureFutures $f$ go.nature.com/mtoodm engraved with the memory's date, and she'd never forget that.

She found the silvery cube with the correct date and cradled it in her hands.

Then she flicked the switch.

Suddenly she was back there again.

She sat beside him in his Jeep, but even in the dim light of passing headlights, she could tell that his face was pale and damp with tears. His hands clenched the wheel. The wipers worked furiously.

Even though it'd been rubbed out from Liza's mind, there was no mistaking the wrongness of this memory. She distinctly remembered a scene from the funeral a few days later, when she'd said over and over, "If only I'd gone with him ..." So what was she doing here now? And if it wasn't her memory, whose was it?

"I'll give you enough to make a start for yourself elsewhere. Pay off your mama's debts. Just call off the wedding." The voice that came from within her, although feminine and familiar, was not Liza's.

"I'm not interested."

"You think she really knows what she's getting into? That she'll really be content with what you have to offer her? What a joke. She'll be crawling back to me, bored out of her mind, before a year's passed."

"I'll take that chance."

"So you won't take my offer?"

"Never."

A thin arm shot out from where Liza watched and grabbed the wheel. His cry filled the car as it swerved over the white line. The woman-who-was-not-Liza flung herself out onto the quickly passing ground.

The car crumpled into a retaining wall.

Even before the memory had fully faded, the Cube clattered to the floor. Liza hunched over, clutching her chest.

All those years ... All those lies... How could she? How dare she?

"Liza?" It was the same voice as in the memory.

Liza reached for the butter knife. She'd killed before; did she still have it in her? But this wasn't just some rival crony; this was Jessa. How could she live with herself?

The glimmer of a Cube caught her eye. She gripped the knife, the answer now crystal clear. Jessa wasn't the only who could forget.

Wendy Nikel lives just west of the Wasatch Mountains in Utah. She enjoys writing speculative fiction, drinking coffee and going on roadtrips. Her website is wendynikel.com. 